\title{
RES IPSA LOQUITUR AND GROSS NEGLIGENCE
}

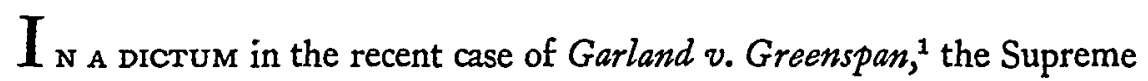
Court of Nevada echoed an apparently unanimous rule ${ }^{2}$ that the doctrine of res ipsa loquitur will not raise an inference $e^{3}$ of gross negligence.

The facts as found by the trial court sitting without a jury showed that one of the plaintiffs ${ }^{4}$ was injured when the defendants' automobile swerved to the left of the highway and then to the right, overturning on striking the right shoulder. The defendant driver had lost control of her car for "some unexplained reason" after passing another automobile at a speed in excess of sixty-five miles an hour and in returning to the right-hand line while negotiating a turn to the right."

Under the Nevada statute, ${ }^{6}$ a guest passenger can recover in tort from the host driver only where injury was caused by the driver's intoxication, wilful misconduct, or gross negligence. The Supreme Court of Nevada, affirming the judgment of the trial court, held that gross negligence or wilful misconduct had not been established as a matter of law,

\footnotetext{
1-Nev. 一, 323 P.zd 27 (1958).

${ }^{2}$ See Harlan v. Taylor, 139 Cal. App. 30, 33 P.2d 422 (1934); Lincoln v. Quick, 133 Cal. App. 433, 24 P.2d 245 (1933); O'Reilly v. Sattler, 141 Fla. 77o, 193 So. 817 (1940); Minkovitz v. Fine, 67 Ga. App. 176, I9 S.E.2d 561 (1942); Rupe v. Smith, 181 Kan. 606, 313 P.2d 293 (1957); Winslow v. Tibbette, 131 Me. 318, 162 Atl. 785 (1932) ; Nyberg v. Kirby, 65 Nev. 42, 188 P.2d roo6, rehearing denied, 165 Nev. 78, I 93 P.2d 850 (1948); Wood v. Shrewsbury, I 77 W. Va. 569, I86 S.E. 294 (1936). Cf. Russell v. Turner, 56 F. Supp. 455 (N.D. Iowa 1944) (recklessness); Johnson v. Trust Co. of Chicago, 343 Ill. App. 647, 99 N.E.2d 715 (1951) (wilful and wanton negligence); Cizek v. Union Stock Yard \& Transit Co., 298 Ill. App. 545, 19 N.E.2d I 10 (1939) (wilful and wanton negligence).

s There is a split of authority upon the question whether res ipsa loquitur should raise an inference or a rebuttable presumption of negligence. Compare Prosser, Res Ipsa Loquitur: A Reply to Professor Carpenter, ro So. CAx. L. REv. 459 (1937), with Carpenter, Res Ipsa Loquitur: A Rejoinder to Professor Prosser, ro So. Cal. L. Rev. 467 (1937), and Shain, Res Ifsa Loquitur, Presumptions and Burden of Proor 23-182 (1945).

- The action was brought by one married couple against another. Only the wives were in the automobile at the time of the accident.

EThe evidence was in dispute whether the defendant driver was speeding at almost eighty miles an hour, was inexperienced in the operation of an automobile, and had been requested either to slow down or to allow her guest to continue the trip in another car.

- NEv. Rev. STAT. \& 4 1.180 (1957).
} 
and observed that "[plaintiffs] have cited us no authority to the effect that [the doctrine of res ipsa loquitur] can supply an inference of gross negligence or wilfulness."

It is not clear that the splintering of negligence into subdivisions of slight, ordinary, and gross does more than compound the difficulty of giving adequate definition to an already amorphous legal concept. ${ }^{8}$ Yet, although interpretations of the meaning of gross negligence have produced notoriously chaotic results, ${ }^{9}$ a number of states $^{10}$ recognize degrees of negligence at common law. At least six other jurisdictions ${ }^{11}$ incorporate gross negligence in automobile guest statutes as a basis of tort liability. But whether or not the concept of gross negligence has anything to recommend it, no clear reason appears why it inust be given the effect of arbitrarily precluding operation of the doctrine of res ipsa loquitur. This latter doctrine, after all, does no more than give appropriate weight in certain situations ${ }^{12}$ to circumstantial

T-Nev. 一, 323 P.2d 27, 28 (1958).

3 "From the time of Justinian until the present day the doctrine of degrees of negligence has engendered confusion-a confusion which is being aggravated rather than abated by the recent statutory enactments on coinparative negligence and 'automobile guest' liability." Elliott, Degrees of Negligence, 6 So. CAL. L. REV. 91, I4I (1933). For a discussion of cases rejecting the concept of degrees of negligence, see id., at 12427. See also 2 HARPER \& James, TORTS 952 (1956); Prosser, Torts 148-49 (2d ed. 1955 ).

- See, e.g., Cope v. Davison, 30 Cal.2d 193, 180 P.2d 873 (1947); Donelan v. Wright, 148 Kan. 287, 81 P.2d 5o (1938); Picarello v. Rodakis, 299 Mass. 33, I I N.E.2d 470 (1937); Elliott, supra note 8, at 120 .

${ }^{10}$ See Merchants' Bank of Vandervoort v. Affholter, 140 Ark. 480, 215 S.W. 648 (1919); Kenny Transfer Co. v. Mayer Bros. Co., 170 Ill. App. 607 (1912); Louisville \& Nashville R.R. v. Brown, 186 Ky. 435, 217 S.W. 686 (1919); Dinardi v. Herook, 328 Mass. 572, 105 N.E.2d 197 (1952); Santoro v. Central New York Power Corp., I89 Misc. 567, 72 N.Y.S.2d I2 (I947); Engle v. Reider, 366 Pa. 4II, 77 A.2d 62 I (195I); Helms v. Universal Atlas Cement Co., 202 F.2d 421 (5th Cir. 1953) (applying Texas law). See also Elliott, supra note 8 , at 12 I nn. 131-38.

${ }^{21}$ Kan. Gen. Stat. ANN. \& 8-122b (1949); Mich. Comp. Laws $§ 256.29$ (1948); Neb. Rev. Stat. \$ 39-740 (1943); Nev. Rev. Stat. \$ 41.180 (1957); N.D. Rev. CODE $§ 39-1503$ (1943); ORe. Rev. Stat. § 30.110 (1953).

21 Res ipsa loquitur is said to apply when the accident is of a kind which would not ordinarily occur in the absence of negligence on the part of someone, the apparent cause of the accident is such that any negligence connected with it would be attributable to the defendant, and the possibility of contributing conduct which would make the plaintiff responsible is eliminated. Prosser, TORTs I99 (2d ed. 1955). "Some authority suggests the additional requirement that evident as to the explanation of the accident must be more readily accessible to the defendant than to the plaintiff. The better view would seem to be that this is not essential, so long as the circuinstances give rise to a reasonable inference of negligence." Ibid. See also 2 HARPER \& JAMES, 
evidence ${ }^{13}$ through creation of a rebuttable presumption or inference of negligence. What mystic quality has gross negligence that it cannot be inferred from circumstantial evidence?

In fact, there may exist in certain other jurisdictions at least a conceptual justification for a rule similar to that asserted in the dictum of the instant case. In some jurisdictions, ${ }^{14}$ gross negligence is assimilated to heedless, wanton, or reckless misconduct. In others, ${ }^{15}$ gross negligence is regarded as simply a greater degree of negligence. Thus, the distinction between ordinary and gross negligence may be either one of kind or of quantity. In a jurisdiction adhering to the distinction in kind, it might be argued that res ipsa loquitur may raise a presumption or inference of a lack of due care, but not of the mental element approaching intent, unnecessary to a finding of negligence but required in a finding of wantoness or recklessness. In a jurisdiction which adopts the distinction in quantity, however, it appears anomalous that res ipsa loquitur should be effective to raise a presumption or inference of a want of due care but not a higher degree of that same want.

It is not suggested that a different result should have obtained in the instant case, but in as much as Nevada adheres to the distinction in quantity, ${ }^{16}$ it appears that the curt rejection of res ipsa loquitur merely

TORTs $\S \S 19.5-19.9$ (1956). For an able analysis of the operation of the doctrine, see Jaffe, Res Ipsa Loquitur Vindicated, I Buffalo L. Rev. I (1951).

${ }^{18}$ Some courts, however, take pains to indicate that res ipsa loquitur is not a rule of "circumstantial evidence, the inference to be drawn by the jury ... resting not upon evidence, . . . but upon a postulate from common experience that accidents of the kind involved do not ordinarily occur in the absence of negligence." Maki v. Murray Hospital, 91 Mont. 251, 263, 7 P.2d 228, 231 (1932). Cf. Belding v. St. Louis Public Service Co., 215 S.W.2d 506 (Mo. 1948); Eickhoff v. Beard-Laney, Inc., 199 S.C. 500, 20 S.E.2d 153 (1942); Johnson v. Ely, 30 Tenn. App. 294, 205 S.W.2d 759 (1947).

${ }^{24}$ See Srajer v. Schwartzman, 364 Kan. 241, 188 P.2d 971 (1948); Froh v. Hein, 76 N.D. 701, 39 N.W.2d 11 (1949); State ex. rel. Zent v. Yanny, 244 Wis. 342, 12 N.W.2d 45 (1943).

${ }^{15}$ See Kastel v. Stieber, 83 Cal. App. Dec. 249, 8 P.2d 474 (1932); Whitfield v. Wheeler, 76 Ga. App. 857, 47 S.E.2d 658 (1948); Hamblen v. Steckley, 148 Neb. 283, 27 N.W.2d 778 (1947); Shaw v. Moore, 104 Vt. 529, 162 Atl. 373 (1932); Alspaugh v. Diggs, 195 Va. 1, 77 S.E.2d 362 (1953).

${ }^{20}$ "The element of culpability which characterizes all negligence is, in gross negligence, magnified to a higher degree as compared with that present in ordinary negligence. Gross negligence is manifestly a smaller amount of watchfulness and circumspection than the circumstances require of a prudent man. But it falls short of being such reckless disregard of probable consequences as is equivalent to a willful and intentional wrong. Ordinary and gross negligence differ in degree of inattention, while 
because of a dearth of authority for such a usage contravenes the logic of that doctrine.

both differ in kind from willful and intentional conduct which is or ought to be known to have a tendency to injure." Hart v. Kline, 61 Nev. 96, 100-101, I 16 P.2d 672,674 (1941), adopting the rule of Altman v. Aronson, 231 Mass. 588, 591, 121 N.E. 505, 506 (1919). 